\title{
Pengembangan teknologi pengendalian hama utama kacang hijau menggunakan biopestisida
}

\author{
The development of mungbean pest control technology \\ by using biopesticide \\ Yusmani Prayogo*, Marida Santi Yudha Ika Bayu \\ Balai Penelitian Tanaman Aneka Kacang dan Umbi \\ Jalan Raya Kendalpayak, Km. 8, Kotak Pos 66, Malang 65101
}

(diterima Februari 2019, disetujui Juli 2020)

\begin{abstract}
ABSTRAK
Hama merupakan salah satu kendala utama dalam upaya peningkatan produksi kacang hijau di Indonesia. Saat ini, pengendalian konvensional menggunakan pestisida sintetik kurang berhasil karena populasi dan kerusakan akibat hama masih tinggi. Penelitian ini bertujuan untuk mengembangkan biopestisida sebagai teknologi pengendalian hama utama kacang hijau yang dibandingkan dengan efikasi pestisida sintetik. Penelitian ini dilaksanakan menggunakan rancangan acak kelompok, lima perlakuan diulang lima kali. Perlakuan yang diuji, yaitu P1: aplikasi serbuk biji mimba (SBM), virus ulat grayak (Virgra) dari Spodoptera litura nuclear polyhedrosis virus, dan konidia cendawan entomopatogen Beauveria bassiana (BeBas) secara preventif; P2: aplikasi SBM, Virgra, dan BeBas berdasarkan ambang ekonomi (AE); P3: aplikasi pestisida sintetik sesuai jadwal; P4: aplikasi pestisida sintetik berdasarkan AE; dan P5: tanpa pengendalian (kontrol). Hasil penelitian menunjukkan bahwa hama yang berkembang adalah ulat grayak (Spodoptera litura (Fabricius)), kutukebul (Bemisia tabaci (Gennadius)), Empoasca sp., Megalurothrips usitatus (Bagnall), kepik coklat (Riptortus linearis (Fabricius)), kepik hijau (Nezara viridula (Linnaeus)), dan hama penggerek polong (Maruca testulalis (Geyer)). Aplikasi biopestisida SBM, Virgra, dan BeBas secara preventif dan aplikasi pestisida sintetik sesuai jadwal efektif menekan populasi hama utama kacang hijau, sedangkan aplikasi biopestisida dan pestisida sintetik berdasarkan AE tidak mampu menekan perkembangan populasi hama utama. Aplikasi biopestisida secara preventif maupun berdasarkan AE lebih aman terhadap kelangsungan hidup musuh alami, sedangkan aplikasi pestisida sintetik dapat membunuh musuh alami yang ada. Biopestisida SBM, Virgra, dan BeBas yang diaplikasikan secara preventif dan terintegrasi berpotensi sebagai inovasi teknologi pengendalian hama utama kacang hijau untuk menggantikan pestisida sintetik.
\end{abstract}

Kata kunci: ambang ekonomi, biopestisida, kacang hijau, pestisida sintetik, teknologi pengendalian

\begin{abstract}
Pests are one of the main obstacles in improving mungbean production in Indonesia. Currently, conventional control by using synthetic pesticides is less successful because the population and damage due to the organism are still high. This study aims to evaluate the mungbean pest control technology by using biopesticide. The experiment was conducted using randomized block design, five treatments and five replicates. The treatments were P1: preventive of neem seed powder (NSP), entompothogenic virus which contain Spodoptera litura nuclear polyhedrosis virus (Virgra), and conidia of entomopathogenic fungi Beauveria bassiana (BeBas) application; P2: SBM, Virgra, and BeBas application based on economic threshold (ET); P3: application of synthetic pesticides based
\end{abstract}

\footnotetext{
*Penulis korespondensi: Yusmani Prayogo. Balai Penelitian Tanaman Aneka Kacang dan Umbi

Jalan Raya Kendalpayak, KM. 8, Kotak Pos 66, Malang 65101

Tel: 0341-801468, Faks: 0341-801496, Email: yusmani.prayogo@yahoo.com
} 
on schedule; P4: application of synthetic pesticides based on ET; and P5: without control. The results showed that the pests were armyworm (Spodoptera litura (Fabricius)), whitefly (Bemisia tabaci (Gennadius)), Empoasca sp., Megalurothrips usitatus (Bagnall), brown stink bug (Riptortus linearis (Fabricius)), green stink bug (Nezara viridula (Linnaeus)), and pod borer (Maruca testulalis (Geyer)). The application of NSP, Virgra, and BeBas, as preventive measures and the application of synthetic pesticides based on schedule effectively were suppressed pest population. In contrast, the application of biopesticides and synthetic pesticides based on ET did not suppress the development of major pests. The application of biopesticide based on ET are safe for the survival of natural enemies. Meanwhile, the application of synthetic pesticides can destroy existing natural enemies. Integrated management of NSP, Virgra, and BeBas, that are applied preventively are potential to be innovative technology for controlling the major mungbean pest to replace synthetic pesticides.

Key words: biopesticides, control technology, economic threshold, mungbean, synthetic pesticides

\section{PENDAHULUAN}

Kacang hijau merupakan sumber protein nabati dan mineral yang cukup tinggi serta harganya cukup stabil bila dibandingkan dengan komoditas pangan lainnya sehingga banyak dibudidayakan petani (Keatinge et al. 2011; Nair et al. 2015; Nanyen et al. 2016).

Kacang hijau umumnya ditanam pada musim kemarau sekitar bulan Juni sampai dengan Agustus sehingga sering diserang hama. Organisme pengganggu tanaman (OPT) yang menyerang tanaman kacang hijau cukup banyak, mulai awal pertumbuhan sampai menjelang panen bahkan hingga di tempat penyimpanan (Singh et al. 2015). Hama utama pada awal pertumbuhan hingga umur dua minggu setelah tanam (MST) adalah lalat kacang (Ophiomyia phaseoli (Tryon)). Pada fase vegetatif, hama yang menyerang adalah ulat grayak (Spodoptera litura (Fabricius)), penggulung daun (Lamprosema indicata (Fabricius)), ulat jengkal (Plusia chalcites Esper), kutukebul (Bemisia tabaci (Gennadius)), pengisap daun (Empoasca sp.), tungau (Tetranychus urticae CL Koch), dan Thrips (Megalurothrips usitatus (Bagnall)). Pada fase generatif hama yang menyerang antara lain pengisap polong (Riptortus linearis (Fabricius)), Nezara viridula (Linnaeus), Piezodorus hybneri (Gmelin)), penggerek polong (Maruca testulalis (Geyer)), dan pemakan polong (Helicoverpa armigera (Hübner)) (Brier 2010; Prayogo \& Bayu 2018).

Upaya pengendalian hama yang dilakukan petani saat ini umumnya hanya mengandalkan keampuhan pestisida sintetik. Namun, populasi OPT di lapangan terus meningkat dan semakin sulit dikendalikan. Kondisi ini terjadi karena penggunaan pestisida sintetik yang tidak tepat jenis, dosis, waktu, frekuensi, maupun cara aplikasi. Kondisi tersebut memicu sebagian besar hama mengalami resistensi dan resurjensi (Razaq et al. 2013; Panizzi 2013). Wang et al. (2010) melaporkan bahwa kutukebul B. tabaci sudah kebal terhadap insektisida sintetik yang beredar sehingga serangga tersebut sudah membentuk banyak biotipe baru yang lebih toleran terhadap insektisida sintetik. Salah satu cara untuk menekan terjadinya resistensi maupun resurjensi, yaitu dengan mengembangkan teknologi pengendalian hama menggunakan agens hayati. Keunggulan agens hayati sebagai biopestisida/insektisida hayati untuk pengendalian hama karena mudah terurai di alam, mudah berkembangbiak, cara perbanyakannya mudah, tidak bersifat toksik terhadap ternak, binatang peliharaan maupun manusia, serta tidak menyebabkan pencemaran air dan lingkungan (Ivase et al. 2017; Sharma et al. 2017; Ruiu 2018).

Pestisida nabati dari serbuk biji mimba (SBM) dosis $50 \mathrm{~g} / 1$ efektif mengendalikan hama daun $(O$. phaseoli, S. litura, Chrysodeixis chalcites (Esper) dan $L$. indicata) pada tanaman kedelai (Indiati et al. 2013; Indiati \& Bedjo 2017). Hasil penelitian Bedjo (2015) menunjukkan bahwa Spodoptera litura nuclear polyhedrosis virus (SINPV) strain JTM 97C memiliki keefektifan yang lebih tinggi dalam membunuh larva S. litura, L. indicata, dan C. chalcites dibandingkan dengan Lepidoptera lainnya. Sementara itu, cendawan entomopatogen Beauveria bassiana dilaporkan efektif membunuh hama pengisap polong ( $R$. linearis, $N$. viridula, dan $P$. hybneri) maupun penggerek polong $M$. testulalis (Prayogo 2017; Prayogo \& Bayu 2018). Penelitian ini bertujuan untuk menguji pengembangan tiga 
jenis biopestisida (SBM, Virgra yang mengandung Spodoptera litura nuclear polyhedrosis virus (SlNPV), dan cendawan entomopatogen Beauveria bassiana (BeBas)) sebagai agens pengendalian hayati hama utama kacang hijau.

\section{BAHAN DAN METODE}

Pengujian teknologi pengendalian hama utama kacang hijau menggunakan biopestisida dilaksanakan pada musim kemarau kedua (MK II), yaitu bulan Juni-Juli 2018 di Instalasi Penelitian dan Pengkajian Teknologi Pertanian (IP2TP) Ngale, Ngawi, Jawa Timur. Rancangan yang digunakan adalah acak kelompok, lima perlakuan diulang lima kali. Perlakuan yang diuji adalah berupa teknologi pengendalian yang terintegrasi dari tiga jenis biopestisida, yaitu serbuk biji mimba (SBM), Virgra yang mengandung Spodoptera litura nuclear polyhedrosis virus (SlNPV), dan konidia cendawan entomopatogen Beauveria bassiana (BeBas) dan pestisida sintetis yang diaplikasikan secara preventif maupun berdasarkan ambang kendali dari masing-masing jenis OPT. Perlakuan adalah P1: SBM, Virgra, dan BeBas yang diaplikasikan secara preventif/ terjadwal (mingguan); P2: SBM, Virgra, dan BeBas yang diaplikasikan berdasarkan ambang ekonomi (AE) (Tabel 1); P3: pestisida sintetis yang diaplikasikan secara terjadwal (mingguan); P4: pestisida sintetis yang diaplikasikan berdasarkan AE; dan P5: tanpa pengendalian (kontrol). SBM hanya diaplikasikan untuk mengendalikan lalat kacang, yaitu pada 7-28 hari setelah tanam (HST), Virgra hanya diaplikasikan untuk mengendalikan hama pemakan daun dan pemakan polong dari Ordo Lepidoptera pada 28-53 HST, sedangkan BeBas hanya diaplikasikan untuk mengendalikan pengisap polong pada 35-53 HST.

\section{Penyiapan biopestisida BeBas}

BeBas merupakan biopestisida yang mengandung konidia cendawan entomopatogen $B$. bassiana. Isolat $B$. bassiana diperoleh dari koleksi di Laboratorium Biopestisida, Balai Penelitian Tanaman Aneka Kacang dan Umbi (Balitkabi) yang berhasil diisolasi dari serangga kepik coklat (R. linearis). Cendawan dikulturkan di dalam cawan petri menggunakan media tumbuh potato dextrose agar (PDA) yang ditambah kitin 5\% dari ekstrak rajungan (Perna viridis) yang diperoleh dari limbah rumah makan rajungan/kepiting di Pandaan (Pasuruan). Rajungan di-keringkan menggunakan sinar matahari kemudian dibuat menjadi tepung sebelum ditambahkan ke media tumbuh. Pada umur 21 hari setelah inokulasi (HSI), biakan cendawan ditambah air $10 \mathrm{ml}$ tiap cawan kemudian koloni cendawan dikerok menggunakan kuas halus hingga seluruh konidia yang terbentuk rontok. Suspensi konidia selanjutnya dimasukkan ke dalam erlenmeyer dan ditambah Tween 80 sebanyak $2 \mathrm{ml} / 1$ selanjutnya dikocok menggunakan shaker selama 60 menit. Suspensi konidia dihitung menggunakan haemocytometer hingga memperoleh kerapatan konidia $10^{7} \mathrm{ml}^{-1}$

Tabel 1. Ambang ekonomi tiap jenis hama pada kacang hijau dan waktu pengendalian

\begin{tabular}{|c|c|c|c|c|}
\hline \multirow{2}{*}{ Jenis hama } & \multirow{2}{*}{ Ambang ekonomi } & \multirow{2}{*}{$\begin{array}{l}\text { Waktu aplikasi } \\
\text { (HST) }\end{array}$} & \multicolumn{2}{|c|}{ Jenis } \\
\hline & & & Biopestisida & Pestisida sintesis \\
\hline Ophiomyia phaseoli & 1 imago/50 rumpun umur 5 HST & $7,14,21,28$ & SBM & Monokrotofos \\
\hline $\begin{array}{l}\text { Spodoptera litura } \\
\text { Lamprosema indicata } \\
\text { Chrysodeixis chalcites }\end{array}$ & $\begin{array}{l}10 \text { individu instar } 3 / 10 \text { rumpun umur } \\
\text { berbunga; } 13 \text { individu/ } 10 \text { rumpun } \\
\text { pengisian polong }\end{array}$ & $28,35,42,49$ & Virgra & Sihalotrin \\
\hline Bemisia tabaci & $\begin{array}{l}1 \text { pasang imago } 20 \text { rumpun umur } \\
21 \mathrm{HST}\end{array}$ & $21,28,35,42$ & BeBas & Tiametoksam \\
\hline $\begin{array}{l}\text { Riptortus linearis } \\
\text { Nezara viridula }\end{array}$ & 1 pasang imago/20 rumpun $35 \mathrm{HST}$ & $35,42,49,53$ & BeBas & Sipermetrin \\
\hline Maruca testulalis & 2 individu/20 rumpun umur $42 \mathrm{HST}$ & $42,49,53$ & Virgra & Sipermetrin \\
\hline
\end{tabular}

SBM: serbuk biji mimba; Virgra: virus entomopatogen mengandung SlNPV; BeBas: biopestisida yang mengandung konidia cendawan entomopatogen Beuveria bassiana; HST: hari setelah tanam. 
sebelum diaplikasikan di lapangan. Aplikasi harus disemprotkan tepat pada serangga sasaran atau bagian tanaman yang diserang hama agar pengendalian berhasil dengan optimal.

\section{Penyiapan biopestisida Virgra}

Virgra, yaitu virus entomopatogen yang mengandung partikel $S$. litura nuclear polyhedrosis virus (SlNPV) yang berfungsi untuk membunuh ulat grayak, akan tetapi juga dapat digunakan untuk mengendalikan hama pemakan daun, seperti L. indicata, C. chalcites maupun larva penggerek polong M. testulalis. Biopestisida ini mengandung partikel SINPV dari isolat JTM97C yang diperoleh dari koleksi Laboratorium Entomologi Balitkabi. Perbanyakan SINPV diawali dengan memelihara serangga $S$. litura di laboratorium hingga memperoleh populasi larva yang memadai. Larva diberi pakan berupa daun kedelai segar setiap hari, setelah terbentuk instar III, larva diberi pakan daun kedelai yang sudah disemprot dengan suspensi SINPV kemudian dipelihara hingga serangga mati. Larva $S$. litura yang sudah mati dikumpulkan kemudian dihancurkan menggunakan mortar atau blender hingga halus dan ditambah air. Suspensi virus dihitung menggunakan haemocytometer hingga memperoleh kerapatan $10^{11} \mathrm{PIB} / \mathrm{ml}$ kemudian ditambah Tween 80 sebanyak $2 \mathrm{ml} / 1$ dan dikocok sebelum diaplikasikan di lapangan. Aplikasi biopestisida yang berasal dari virus entomopatogen harus menempel pada seluruh organ tanaman khususnya daun kacang hijau yang diharapkan akan dimakan oleh larva $S$. litura, $L$. indicata, C. chalcites maupun polong sebagai sumber pakan bagi larva M. testulalis.

\section{Penyiapan biopestisida SBM}

SBM, yaitu pestisida nabati dari serbuk biji mimba yang mengandung senyawa azadiraktin, biopestisida ini digunakan untuk menekan atau menghambat perkembangan populasi lalat kacang maupun hama lainnya. Formulasi SBM yang digunakan diperoleh dari Balai Penelitian Tanaman Pemanis dan Serat (Balitas). Dosis aplikasi pestisida nabati SBM $50 \mathrm{~g} / 1$ yang sebelum diaplikasikan, SBM terlebih dahulu direbus hingga suhu $100{ }^{\circ} \mathrm{C}$ dengan tujuan agar lebih banyak senyawa azadiraktin yang terekstrak. Aplikasi SBM harus mengenai organ tanaman yang berumur 7, 14, 21, dan 28 HST.

\section{Penanaman tanaman perlakuan}

Kacang hijau ditanam pada petak yang berukuran $4 \mathrm{~m}$ x $5 \mathrm{~m}$ per perlakuan per ulangan dengan jarak tanam $40 \mathrm{~cm} \times 20 \mathrm{~cm}$. Tanah diolah hingga gembur kemudian dicampur pupuk organik sebanyak 4 t/ha. Tanaman dipupuk dengan $37,5 \mathrm{~kg} \mathrm{~N} / \mathrm{ha}, 73,5 \mathrm{~kg}_{2} \mathrm{O}_{5} / \mathrm{ha}$, dan $37,5 \mathrm{~kg} \mathrm{~K}_{2} \mathrm{O}$ yang diberikan pada saat tanam. Penyiangan dilakukan dua kali pada umur 14 dan 28 HST.

\section{Pengamatan}

Variabel yang diamati adalah (1) jenis dan populasi hama; (2) intensitas serangan hama pemakan daun; (3) intensitas serangan hama pemakan dan pengisap polong meliputi polong rusak (polong hampa dan polong tergerek); (4) jenis dan populasi musuh alami dengan cara menjaring menggunakan sweep net atau pengamatan secara visual pada 10 rumpun tanaman; (5) bobot biji ubinan seluas $20 \mathrm{~m}^{2}$. Jenis dan populasi arthropoda diamati dari 10 rumpun tanaman contoh pada luasan $20 \mathrm{~m}^{2}$.

\section{Analisis data}

Kehilangan hasil kedelai akibat hama perusak polong dianalisis mengikuti metode yang dikembangkan oleh Karmawati \& Tengkano (1988), Arifin \& Tengkano (2008), yaitu

$$
\mathrm{KH}=\frac{\mathrm{A}}{\mathrm{B}} \times 100 \% \text {, dengan }
$$

KH: kehilangan hasil (\%); A: jumlah polong terserang; B: jumlah polong yang diamati.

Semua data hasil pengamatan dikumpulkan selanjutnya dianalisis menggunakan program Minitab 14. Setelah itu, apabila terdapat perbedaan yang nyata antar perlakuan maka dilanjutkan dengan uji jarak berganda (Duncan's multiple range test) pada taraf nyata $\alpha=0,05$.

\section{HASIL}

\section{Jenis dan populasi artropoda}

Hasil pengamatan visual dan penangkapan menggunakan jaring (sweep net) pada 10 rumpun tanaman pada umur 49 HST diperoleh tujuh jenis serangga yang berstatus sebagai hama, yaitu S. litura, Empoasca sp., M. usitatus, B. tabaci, R. linearis, N. viridula, dan M. testulalis (Tabel 2). Populasi larva $S$. litura tiap 10 rumpun tanaman 
pada P1 dan P3 lebih rendah jika dibandingkan dengan perlakuan lainnya. Populasi B. tabaci dan $M$. testulalis lebih tinggi pada semua perlakuan jika dibandingkan dengan populasi hama lainnya, sedangkan populasi Empoasca sp. lebih tinggi pada perlakuan P2 dan P4.

Hama polong yang ditemukan adalah penggerek polong $M$. testulalis (Lepidoptera: Crambidae). Populasi hama ini yang terendah terjadi pada $\mathrm{P} 3$ dan $\mathrm{P} 1$, dan semakin meningkat pada P5. Hama polong lain yang ditemukan adalah pengisap yang terdiri atas kepik coklat ( $R$. linearis) dan kepik hijau ( $N$. viridula). Populasi kedua jenis pengisap polong ini hanya di bawah 3 individu/10 rumpun tanaman pada $\mathrm{P} 1$ dan $\mathrm{P} 3$. Pada perlakuan tanpa pengendalian, populasi kedua jenis hama pengisap polong mencapai 7 kali lipat/10 rumpun tanaman

Artropoda yang teramati tidak hanya serangga hama, akan tetapi juga ditemukan serangga berguna yang berperan sebagai musuh alami, yaitu predator dan parasitoid. Tiga jenis predator yang ditemukan pada pertanaman kacang hijau, yaitu Oxyopes sp., Paederus sp., dan Coccinella sp., yang mempunyai kemampuan predasi cukup tinggi terhadap hama utama. Kondisi ini dapat dilihat dari rerata populasi hama utama yang ditemukan pada perlakuan P1 dan P2 terlihat lebih rendah jika dibandingkan dengan perlakuan P5. Serangga yang berperan sebagai parasitoid ada dua jenis, yaitu Trichogramma sp. dan Telenomus sp. Kelima jenis musuh alami tersebut banyak ditemukan pada perlakuan biopestisida, baik yang diaplikasikan secara preventif (P1) maupun aplikasi berdasarkan nilai AE (P2). Rerata populasi parasitoid Telenomus sp. tampak lebih mendominasi pada perlakuan P1 dan P2 masingmasing 12 individu dan 42,5 individu/10 rumpun tanaman (Tabel 3).

\section{Polong rusak}

Jumlah polong hampa terbanyak ditemukan pada perlakuan P5, yaitu mencapai 5,5 polong per tanaman (Tabel 4), tidak berbeda nyata dengan perlakuan P2. Jumlah polong hampa terendah, yaitu hanya 2,5 polong per tanaman yang terdapat pada P3, tidak berbeda nyata dengan P1 dan P4 yang berkisar 3-3,5 polong/tanaman. Jumlah polong tergerek oleh $M$. testulalis cukup rendah pada P1, P2, dan P3, yaitu berkisar hanya 1,82,0 polong per tanaman. Jumlah polong tergerek tertinggi ditemukan pada perlakuan P5, yaitu mencapai 5 polong per tanaman, tidak berbeda nyata dengan perlakuan $\mathrm{P} 4$.

\section{Bobot biji}

Hasil pengamatan menunjukkan bahwa ratarata bobot biji berkisar $0,7-1,0$ t/ha (Tabel 4). Bobot biji tertinggi diperoleh dari perlakuan P3, yaitu mencapai 1,0 t/ha dan tidak berbeda nyata dengan P1, yaitu 1,0 t/ha. Bobot biji terendah terdapat pada $\mathrm{P} 5$, yaitu hanya $0,7 \mathrm{t} / \mathrm{ha}$.

Tabel 2. Rata-rata populasi arthropoda pada 10 rumpun kacang hijau yang diaplikasi menggunakan biopestisida (SBM, Virgra, BeBas) dan pestisida sintesis pada umur 49 HST

\begin{tabular}{lccccc}
\hline \multirow{2}{*}{ Jenis arthropoda } & \multicolumn{5}{c}{ Populasi arthropoda* } \\
\cline { 2 - 6 } & P1 & P2 & P3 & P4 & P5 \\
\hline Spodoptera litura & $1,9 \mathrm{a}$ & $10,9 \mathrm{bc}$ & $7,5 \mathrm{ab}$ & $19,0 \mathrm{c}$ & $26,5 \mathrm{~d}$ \\
Empoasca sp. & $7,1 \mathrm{a}$ & $23,0 \mathrm{bc}$ & $12,4 \mathrm{ab}$ & $21,4 \mathrm{~b}$ & $47,3 \mathrm{~d}$ \\
Megalurothrips usitatus & $11,7 \mathrm{ab}$ & $23,1 \mathrm{c}$ & $4,5 \mathrm{a}$ & $29,0 \mathrm{~cd}$ & $42,1 \mathrm{e}$ \\
Bemisia tabaci & $19,0 \mathrm{a}$ & $34,6 \mathrm{bc}$ & $46,8 \mathrm{c}$ & $66,9 \mathrm{~d}$ & $92,3 \mathrm{e}$ \\
Riptortus linearis & $2,4 \mathrm{a}$ & $9,7 \mathrm{bc}$ & $0,5 \mathrm{a}$ & $11,0 \mathrm{c}$ & $22,5 \mathrm{~d}$ \\
Nezara viridula & $1,7 \mathrm{a}$ & $6,1 \mathrm{bc}$ & $1,0 \mathrm{a}$ & $10,9 \mathrm{c}$ & $21,0 \mathrm{~d}$ \\
Maruca testulalis & $9,9 \mathrm{~b}$ & $15,1 \mathrm{~cd}$ & $4,1 \mathrm{a}$ & $12,5 \mathrm{c}$ & $20,0 \mathrm{de}$ \\
\hline
\end{tabular}

*: angka dalam tiap baris yang diikuti notasi sama, tidak berbeda nyata antar perlakuan pada uji DMRT 0,05.

P1: aplikasi biopestisida (SBM, Virgra, BeBas) secara preventif (tiap minggu); P2: aplikasi biopestisida (SBM, Virgra, BeBas) yang diaplikasikan berdasarkan ambang ekonomi (AE); P3: aplikasi pestisida sintetis yang diaplikasikan secara berjadwal (tiap minggu); P4: aplikasi pestisida sintetis berdasarkan AE; dan P5: tanpa pengendalian (kontrol). 
Tabel 3. Rata-rata populasi musuh alami pada 10 rumpun tanaman yang diaplikasi menggunakan biopestisida dan pestisida sintesis pada umur 49 HST

\begin{tabular}{lccccc}
\hline \multirow{2}{*}{ Jenis musuh alami } & \multicolumn{5}{c}{ Populasi musuh alami* } \\
\cline { 2 - 6 } & $\mathrm{P} 1$ & $\mathrm{P} 2$ & $\mathrm{P} 3$ & $\mathrm{P} 4$ & $\mathrm{P} 5$ \\
\hline Oxyopes $\mathrm{sp}$. & $4,2 \mathrm{ab}$ & $13,5 \mathrm{c}$ & $0,5 \mathrm{a}$ & $0,5 \mathrm{a}$ & $13,5 \mathrm{c}$ \\
Paederus $\mathrm{sp}$. & $9,8 \mathrm{~b}$ & $16,9 \mathrm{bc}$ & $1,4 \mathrm{a}$ & $0,5 \mathrm{a}$ & $21,9 \mathrm{~cd}$ \\
Coccinella sp. & $4,7 \mathrm{a}$ & $12,0 \mathrm{~b}$ & $0,0 \mathrm{a}$ & $1,3 \mathrm{a}$ & $21,6 \mathrm{c}$ \\
Trichogramma sp. & $11,5 \mathrm{~b}$ & $19,5 \mathrm{bc}$ & $0,0 \mathrm{a}$ & $1,4 \mathrm{a}$ & $38,6 \mathrm{~d}$ \\
Telenomus sp. & $12,0 \mathrm{~b}$ & $42,5 \mathrm{c}$ & $0,5 \mathrm{a}$ & $2,5 \mathrm{a}$ & $72,5 \mathrm{~d}$ \\
\hline
\end{tabular}

*: angka dalam tiap baris yang diikuti notasi sama, tidak berbeda nyata antar perlakuan pada uji DMRT 0,05.

P1: aplikasi biopestisida (SBM, Virgra, BeBas) secara preventif (tiap minggu); P2: aplikasi biopestisida (SBM, Virgra, BeBas) yang diaplikasikan berdasarkan ambang ekonomi (AE); P3: aplikasi pestisida sintetis yang diaplikasikan secara berjadwal (tiap minggu); P4: aplikasi pestisida sintetis berdasarkan AE; dan P5: tanpa pengendalian (kontrol).

Tabel 4. Pengaruh aplikasi biopestisida dan pestisida sintetik terhadap jumlah polong hampa, polong tergerek, dan bobot biji kacang hijau

\begin{tabular}{lccc}
\hline Perlakuan & Jumlah polong hampa* & Jumlah polong tergerek* & Bobot biji (t/ha)* $^{*}$ \\
\hline P1 & $3,0 \mathrm{a}$ & $2,0 \mathrm{ab}$ & $1,01 \mathrm{ab}$ \\
P2 & $4,5 \mathrm{bc}$ & $1,9 \mathrm{a}$ & $0,94 \mathrm{c}$ \\
P3 & $2,5 \mathrm{a}$ & $1,8 \mathrm{a}$ & $1,02 \mathrm{a}$ \\
P4 & $3,5 \mathrm{ab}$ & $4,0 \mathrm{c}$ & $0,95 \mathrm{c}$ \\
P5 & $5,5 \mathrm{bc}$ & $5,0 \mathrm{~cd}$ & $0,72 \mathrm{~d}$ \\
\hline
\end{tabular}

*: angka selajur yang diikuti notasi yang sama tidak berbeda nyata antar perlakuan pada uji DMRT 0,05.

P1: aplikasi biopestisida (SBM, Virgra, BeBas) secara preventif (tiap minggu); P2: aplikasi biopestisida (SBM, Virgra, BeBas) yang diaplikasikan berdasarkan ambang ekonomi (AE); P3: aplikasi pestisida sintetis yang diaplikasikan secara berjadwal (tiap minggu); P4: aplikasi pestisida sintetis berdasarkan AE; dan P5: tanpa pengendalian (kontrol).

\section{PEMBAHASAN}

Keefektifan teknologi pengendalian menggunakan biopestisda yang diuji terlihat dari rendahnya populasi serta jenis hama yang terdapat pada pertanaman, stabilnya populasi musuh alami, serta rendahnya tingkat serangan/kerusakan tanaman yang disebabkan oleh hama target bila dibandingkan dengan populasi hama pada penggunaan insektisida sintetis.

Pada penelitian ini, keragaan tanaman kacang hijau yang ditanam pada MK II tampak kurang bagus karena terjadi peledakan berbagai jenis OPT, baik hama maupun penyakit dengan populasi cukup tinggi. Rendahnya populasi ulat grayak pada perlakuan P1 (aplikasi Virgra preventif) disebabkan oleh biopestisida Virgra efektif membunuh larva ulat grayak. Hasil penelitian ini sejalan dengan yang dilaporkan oleh Mwanauta et al. (2015) tentang efektivitas SlNPV terhadap ulat grayak. Selain itu, rendahnya populasi ulat grayak juga karena adanya aplikasi SBM yang mengandung senyawa azadiraktin, nimbin, dan salanin yang berfungsi sebagai penolak makan, mempengaruhi syaraf yang memproduksi hormon ekdison untuk proses ganti kutikula (moulting) serangga, serta menurunkan vertilitas serangga maupun nematoda sehingga produksi telur yang dihasilkan sangat terbatas (Achio et al. 2012; Malik et al. 2017). Rerata populasi larva S. litura yang rendah pada perlakuan P1 dan P2 juga dipengaruhi oleh adanya peran aktif musuh alami parasitoid Telenomus sp. yang tinggi sehingga mampu menekan perkembangan S. litura. Menurut Pomari-Fernandes et al. (2013), parasitoid T. remus memiliki kemampuan yang tinggi dalam memarasitasi serangga inang terutama stadia telur dan larva S. litura.

Penggunaan insektisida sintesis secara preventif maupun berdasarkan AE tidak mampu mengendalikan B. tabaci karena populasi hama tersebut semakin banyak. Hasil penelitian ini 
sejalan dengan hasil penelitian sebelumnya yang menyebutkan bahwa aplikasi insektisida sintesis yang tidak tepat dosis dan sasaran dapat memicu terjadinya peledakan populasi B. tabaci (AbdelRahman et al. 2018; Fang et al. 2018). Lebih lanjut disebutkan bahwa peningkatan populasi $B$. tabaci juga dapat terjadi karena seluruh musuh alami yang ada mati terbunuh akibat resistensi dan resurjensi (Naveen et al. 2017; Ghosal \& Chatterjee 2018).

Serangga Thrips sp. dan B. tabaci selain berstatus sebagai hama juga merupakan vektor virus penting yang dapat menyebabkan gagal panen kacang hijau sehingga keberadaan serangga tersebut perlu diwaspadai. Menurut Pande (2013) dan Mohan et al. (2014), salah satu jenis virus yang ditularkan melalui B. tabaci adalah Mungbean yellow mosaic virus (MYMV). Jayappa (2017) dan Anokhe et al. (2018) menyatakan bahwa kehilangan hasil kacang hijau akibat infeksi MYMV, yaitu mencapai $80 \%$.

Populasi Empoasca sp. ditemukan cukup tinggi pada pertanaman kacang hijau dan terjadi pada hampir semua perlakuan pengendalian. Serangga ini termasuk hama pengisap daun yang cukup penting karena juga berfungsi sebagai vektor virus pada berbagai jenis tanaman (Acosta et al. 2017). Murray et al. (2015) menginformasikan bahwa kehilangan hasil akibat serangan Empoasca sp. berkisar 59-70\%. Oleh karena itu, hama Empoasca sp. pada tanaman kacang hijau perlu mendapat perhatian agar tidak menyebabkan kerugian hasil.

Keberadaan hama penggerek polong juga perlu mendapat perhatian karena hama tersebut mampu menyebabkan kehilangan hasil mencapai 55\% (Karel 1985; Zahid et al. 2008). Hasil penelitian ini mengindikasikan bahwa pengendalian menggunakan insektisida sintesis secara terjadwal (P3) dan aplikasi biopestisida secara preventif (P1) lebih efektif menekan populasi penggerek polong kacang hijau. Efikasi perlakuan P1 disebabkan oleh dampak akumulasi aplikasi biopestisida SINPV, SBM, dan BeBas yang mengandung konidia cendawan entomopatogen B. bassiana sehingga populasi hama penggerek polong tidak berkembang. Mehinto et al. (2014) melaporkan bahwa cendawan $B$. bassiana cukup efektif membunuh penggerek polong hingga menyebabkan mortalitas mencapai 79\%. Selain itu, Subhasree (2013) menyatakan bahwa senyawa 76 azadiraktin dari SBM juga mampu menekan populasi penggerek polong.

Populasi predator Paederus sp. tampak lebih mendominasi jika dibandingkan dengan Oxyopes sp. maupun Coccinella sp. Ketiga jenis predator tersebut khususnya Paederus sp. dan Coccinella sp. mempunyai kemampuan predasi yang cukup tinggi dalam membunuh mangsa seperti $B$. tabaci maupun hama lainnya (Udiarto et al. 2012; Prayogo \& Bayu 2018). Selain itu, Oxyopes sp. memiliki kapasitas predasi yang cukup tinggi dalam memangsa hampir seluruh jenis hama dari Ordo Diptera, Orthoptera, Coleoptera, Hemiptera, Homoptera, dan Lepidoptera (Riaz \& Naqvi 2014).

Hasil pengamatan ini mengindikasikan bahwa aplikasi biopestisida yang diaplikasikan secara preventif melalui inundasi maupun aplikasi berdasarkan ambang kendali relatif lebih aman terhadap kelangsungan hidup musuh alami jika dibandingkan dengan aplikasi menggunakan pestisida sintesis. Hampir seluruh jenis musuh alami, baik predator maupun parasitoid diketahui lebih rentan terhadap sebagian besar senyawa pestisida sintesis (Pratissoli et al. 2010; Fiedler \& Sosnowska 2014). Selain itu, aplikasi biopestisida yang mengandung azadiraktin (SBM) aman terhadap parasitoid Trichogramma minutum Riley (Hymenoptera: Trichogramatoidae) (Lyons et al. 2003). Wu et al. (2015) juga menyatakan bahwa biopestisida dari cendawan entomopatogen $B$. bassiana kompatibel dengan predator Neoseiulus barkeri Hughes.

Pengendalian menggunakan biopetisida maupun pestisida sintesis berdasarkan ambang kendali belum mampu menekan kerusakan polong dari serangga pengisap. Hal ini terlihat dari tingginya populasi pengisap polong pada MK II sehingga pengendalian berdasarkan ambang kendali belum mampu menurunkan populasi kedua jenis hama tersebut. Rendahnya jumlah polong rusak pada perlakukan $\mathrm{P} 3$ mengindikasikan bahwa aplikasi insektisida sintesis berbahan aktif sipermetrin secara terjadwal lebih efektif dalam menekan populasi pengisap polong di awal stadia sehingga kerusakan yang ditimbulkan juga rendah. Tengkano et al. (2011) melaporkan bahwa aplikasi insektisida sintesis dari sipermetrin dan deltametrin secara terjadwal mampu mengendalikan hama pengisap polong $R$. linearis dan $N$. viridula hingga 
95\%, sedangkan rendahnya kerusakan polong pada perlakuan P1 disebabkan oleh efikasi biopestisida BeBas yang mampu membunuh seluruh stadia hama $R$. linearis dan $N$. viridula. Hasil penelitian Prayogo (2012) dan Prayogo \& Tantawizal (2015) mengidikasikan bahwa cendawan $B$. bassiana menyebabkan mortalitas kepik coklat (R. linearis) hingga mencapai $80 \%$. Bahkan, cendawan $B$. bassiana memiliki keunggulan yang tidak dimiliki oleh agens pengendalian lainnya, yaitu bersifat ovisidal (ovicidal) yang mampu membunuh stadium telur berbagai jenis serangga hama (Prayogo 2012; Tumuhaise et al. 2015; Saeed et al. 2017).

Polong tergerek ditandai dengan adanya lubang pada kulit polong akibat gerekan larva M. testulalis berada di dalam polong pada waktu pengisian hingga pemasakan biji. Jumlah polong tergerek pada perlakuan P1 rendah karena efikasi penggunaan biopestisida Virgra yang mengandung SINPV yang mampu membunuh stadium larva penggerek polong. Selain itu, rendahnya jumlah polong tergerek diduga karena pengaruh efikasi cendawan $B$. bassiana yang mempunyai kemampuan membunuh seluruh stadium serangga mulai telur, nimfa, dan imago sehingga populasi serangga hama tidak berkembang dan tidak menyebabkan kerusakan biji (Prayogo 2013). Efikasi perlakuan P3 disebabkan oleh insektisida sintesis (sipermetrin) yang diaplikasikan secara terjadwal mulai umur 35-53 HST sehingga populasi hama penggerek polong tidak mampu berkembang atau serangga yang ada tidak menyukai tanaman yang sudah mengalami akumulasi oleh paparan pestisida sintesis karena aplikasi dilakukan tiap minggu.

Aplikasi insektisida sintesis (sipermetrin) untuk pengendalian hama penggerek polong yang didasarkan pada AK belum mampu menekan kerusakan polong. Kondisi ini disebabkan larva $M$. testulalis berkembang di dalam polong sehingga aplikasi insektisida sintetsis tersebut tidak mampu menjangkau serangga sasaran. Oleh karena itu, nilai ambang kendali untuk penggerek polong yang disebabkan oleh $M$. testulalis perlu dikaji ulang agar teknologi pengendalian yang diterapkan lebih akurat sehingga tidak mengakibatkan kerugian. Menurut Zahid et al. (2008) nilai ambang kendali untuk Maruca spp., yaitu berkisar 0,87-1,16 larva tiap $\mathrm{m}^{2}$. Sementara itu, nilai ambang kendali suatu OPT mengalami fluktuasi karena dipengaruhi oleh beberapa faktor, di antaranya jenis komoditas, harga pasar, musim, jenis OPT, populasi maupun status OPT (Arifin \& Tengkano 2010).

Bobot biji yang diperoleh dari hasil penelitian ini lebih rendah dari potensi hasil maupun rata-rata produktivitas yang dimiliki varietas unggul Vima 1 yang mampu mencapai 1,7 t/ha (BALITKABI 2016). Kejadian ini disebabkan karena tanaman kacang hijau yang ditanam pada MK II (JuniAgustus) mengalami cekaman biotik akibat diserang berbagai jenis hama maupun penyakit dengan intensitas cukup tinggi sehingga hasil yang diperoleh juga rendah dan jauh di bawah potensi hasil. Aplikasi pestisida sintesis dan biopestisida berdasarkan nilai ambang kendali menunjukkan hasil biji yang lebih rendah jika dibandingkan dengan aplikasi secara terjadwal. Aplikasi pestisida sintesis maupun biopestisida berdasarkan ambang kendali tidak mampu membunuh OPT dalam rentang waktu yang singkat sehingga organisme tersebut tetap merusak tanaman. Selain itu, banyak biji yang hampa akibat serangan $R$. linearis dan $N$. viridula serta tergerek oleh M. testulalis. Hasil penelitian Ogunwolu (1990) mengindikasikan bahwa kehilangan hasil kacang hijau akibat serangan M. testulalis, yaitu berkisar $48-72 \%$ jika tidak dilakukan upaya pengendalian. Selain itu, pada perlakuan P5 juga banyak ditemukan populasi kutukebul B. tabaci selain hama ulat grayak ( $S$. litura) yang serangannya mempengaruhi fotosintesis daun kacang hijau.

Dari hasil penelitian ini dapat diperoleh informasi bahwa tanaman kacang hijau yang ditanam pada bulan Juni-Agustus atau MK II mengalami cekaman OPT yang maksimal sehingga jika tidak dilakukan pengendalian maka akan mengalami kerugian cukup besar.

\section{KESIMPULAN}

Biopestisida yang terdiri atas SBM (serbuk biji mimba), Virgra (S. litura nuclear polyhedrosis virus), dan BeBas (B. bassiana), yang diaplikasikan secara preventif dan terintegrasi dengan cara inundasi dapat menekan serangan hama utama pada kacang hijau dan efikasinya setara dengan 
efikasi pestisida sintesis yang diaplikasikan secara terjadwal. Biopestisida yang diaplikasikan secara preventif maupun pestisida sintesis yang diaplikasikan berdasarkan ambang ekonomi tidak mampu menekan kerusakan tanaman dari serangan hama utama kacang hijau pada MK II. Aplikasi biopestisida lebih aman dalam mempertahankan kelangsungan hidup predator maupun parasitoid, sedangkan aplikasi insektisida sintesis hampir membunuh seluruh musuh alami yang ada.

\section{UCAPAN TERIMA KASIH}

Terima kasih kami sampaikan kepada Badan Litbang Pertanian yang telah memberikan dana melalui DIPA untuk terlaksananya penelitian ini hingga selesai.

\section{DAFTAR PUSTAKA}

Abdel-Rahman YA, Abd-Ella AA, Gaber AS, AbouElhagag GH. 2018. Impact of weather factors and certain insecticides on the population density of cotton whitefly Bemisia tabaci (Genn.) (Homoptera; Aleyrodidae). Journal of Phytopathology and Pest Management 5:35-48.

Achio S, Ameko E, Kutsanedzie F, Alhassan S. 2012. Insecticidal effects of various neem preparations against some insects of agricultural and public health concern. International Journal of Research in Bioscience 1:11-19.

Acosta KL, Zamora L, Pinol B, Quinones ML, Ramos PL, Luis M, Va-Lopez NE, Arocha Y. 2017. Empoasca papaya Oman 1937 (Homoptera: Cicadellidae) the stimultanous vector of phytoplasma and rickettsia associated with bunchy top symptom in Cuba. Anales de Biologia 39:34-42. doi: https://doi.org/10.6018/ analesbio.39.03.

Anokhe A, Mandal B, Subramanian S. 2018. Characterization of Mungbean yellow mosaic virus transmission by Asia I and Asia II-1 genetic group of Bemisia tabaci Gennadius. Journal of Entomology and Zoology Studies 6:487-491.

Arifin M, Tengkano W. 2008. Tingkat kerusakan ekonomi hama kepik coklat pada kedelai. Penelitian Pertanian 27:47-54.

Arifin M, Tengkano W. 2010. Tingkat kerusakan ekonomi hama kepik punggung bergaris Piezodorus hybneri pada kedelai. Jurnal
Penelitian Pertanian Tanaman Pangan 29:4249.

[BALITKABI]. 2016. Deskripsi Varietas Unggul Kacang Hijau. Balai Penelitian Tanaman Aneka Kacang dan Umbi. Malang: Balitkabi Malang.

Bedjo. 2015. Efektivitas Spodoptera litura nuclear polyhedrosis virus terhadap larva Helicoverpa armigera. Di dalam: Rahmianna AA et al. (Eds.), Prosiding Seminar Nasional Hasil Penelitian Tanaman Aneka Kacang dan Umbi (Malang, 19 Mei 2015). hlm. 237-243. Malang: Balitkabi.

Brier H. 2010. Integrated pest management in Australian mungbean and soybeans, swings, rounddobouts and conundrums. Di dalam: George-Jaeggli B, Jordan DJ (Eds.), Proceedings of The $1^{\text {st }}$ Australian Summer Grains Conference, Gold Coast (Australia, 21-24 Juni 2010). hlm. 1-10. Gold Coast: Queensland Alliance for Agriculture and Food Innovation School of Biological Sciences Publications.

Fang Y, Wang J, Cuo C, Wang R. 2018. Lethal and sublethal effects of clothionidin on the development and reproduction of Bemisia tabaci (Homoptera: Aleyrodidae) MED and MEAMI. Journal of Insect Science 18:1-6. doi: https:// doi.org/10.1093/jisesa/iey025.

Fiedler Z, Sosnowska D. 2014. Side effects of fungicides and insecticides on predatory mites, in laboratory conditions. Journal of Plant Protection Research 54:349-353. doi: https:// doi.org/10.2478/jppr-2014-0052.

Ghosal A, Chatterjee M. 2018. Insecticide induced resurgence study of whitefly in cotton and tomato. Journal of Animal Science 2:1-6.

Indiati SW, Suharsono, Bedjo. 2013. Pengaruh aplikasi serbuk biji mimba, Spodoptera litura nuclear polyhedrosis virus dan varietas tahan terhadap perkembangan ulat grayak pada kedelai. Jurnal Penelitian Pertanian, Tanaman Pangan 32:43-49. doi: https://doi.org/10.21082/ jpptp.v1n3.2017.p243-253.

Indiati SW, Bedjo. 2017. Integrasi varietas tahan dan bioinsektisida untuk pengendalian ulat perusak daun kedelai. Jurnal Penelitian Pertanian Tanaman Pangan 1:243-252.

Ivase TJP, Nyakuma BB, Obenyi BU, Balogun AD, Hassan MN. 2017. Current status, challenges, and prospects of biopesticide utilization in Nigeria. Acta Universitastis Sapientiae Agriculture and Environmental 9:95-106. doi: https://doi. org/10.1515/ausae-2017-0009.

Jayappa, Ramappa HK, Sab J, Devamani BD. 2017. Status of the Mungbean yellow mosaic virus (MYMV) disease in Southeren Karnataka. 
International Journal of Pure and Applied Bioscience 5:238-244. doi: https://doi. org/10.18782/2320-7051.3020.

Keatinge JDH, Easdown WJ, Yang RY, Chadha ML, Shanmugasundaram S. 2011. Overcoming chronic malnutrition in a future warming world: The key importance of mungbean and vegetable soybean. Euphytica 180:129-141. doi: https:// doi.org/10.1007/s10681-011-0401-6.

Karel AK. 1985. Yield losses from and control of bean pod borer Maruca testulalis (Lepidoptera: Pyralidae) and Helicoverpa armigera (Lepidoptera: Noctuidae). Journal of Economic Entomology 78:1323-1326. doi: https://doi. org/10.1093/jee/78.6.1323.

Karmawati E, Tengkano W. 1988. Pola sebaran dan metode penarikan contoh pengisap polong kedelai. Di dalam: Seminar Hasil Penelitian Tanaman Pangan (Bogor, 17-18 Desember 1988). Bogor: Balitan.

Lyons DB, Helson BV, Bouchier RS, Jones GC, Mc Farlane JW. 2003. Effects of azadirachtin-based insecticides on the egg parasitoid Trichogramma minutum (Hymenoptera: Trichogrammatoidae). The Canadian Entomologist 135:685-695. doi: https://doi.org/10.4039/n02-113.

Malik AQ, Syed TS, Sahito HA, Abbasi NA, Jalbani NA, Mastoi SM, Mangrio WM, Jatoi FA. 2017. Effect of sublethal concentration of Azadirahcta indica on biology and weight of Spodoptera litura on cauliflower under laboratory conditions. Journal of Entomology and Zoology Studies 5: 1091-1095.

Menhinto JT, Atachi P, Kpindou OKD, Tamo M. 2014. Pathogenicity of entomopathogenic fungi Metarhizium anisopliae and Beauveria bassiana on larvae of the legume pod borer Maruca vitrata (Lepidoptera: Crambidae). ARPN Journal of Agricultural and Biological Science 9:55-64.

Mohan S, Sheeba A, Murugan E, Ibrahim SM. 2014. Screening of mungbean germplasm for resistance to Mungbean yellow mosaic virus under natural condition. Indian Journal of Science and Technology 7:891-896. doi: https:// doi.org/10.17485/ijst/2014/v7i7.1.

Murray JD, Michaels TE, Pauls KP, Cordona C, Schaafsma AW. 2015. Yield and insect injury in leafhopper (Empoasca fabae Harris) and (E. kraemeri Ross \& Moore) infested dry beans in Ontario and Colombia. Canadian Journal of Plant Science 84:891-900. doi: https://doi. org/10.4141/P02-161.

Mwanauta RW, Mtei KM, Ndakidemi PA. 2015. Potential of controlling common bean insects pests bean stem maggot (Ophiomyia phaseoli), Ootheca (Ootheca bennigseni) and aphids (Aphis fabae) using agronomic, biological control botanical practices in field. Agriculture Science 6:489-497. doi: https://doi.org/10.4236/ as.2015.65048.

Nair RM, Thavarajah D, Thavarajah P, Giri RR, Ledesma D, Yang RY, et al. 2015. Mineral and phenolic concentrations of mungbean [Vigna radiata (L.) R. Wilczek var. radiata] grown in semi-arid tropical India. Journal of Food Composition and Analysis 39:23-32. doi: https:// doi.org/10.1016/j.jfca.2014.10.009.

Nanyen D, Dooshima IB, Julius A, Benbella I. 2016. Nutritional composition, physical and sensory properties of cookies from wheat, acha, and mungbean composite flours. Intrernational Journal of Nutrition and Food Science 5:401406. doi: 10.11648/j.ijnfs.20160506.15.

Naveen NC, Chaubey R, Kumar D, Rebijith KB, Rajagopal R, Subrahmanyam B, Subrahmanian S. 2017. Insectcide resistance status in the whitefly Bemisia tabaci genetic group Asia I, Asia II-1 and Asia II-7 on the Indian Subcontinent. Scientific Reports (7-40634):1-15. doi: https:// doi.org/10.1038/srep40634.

Ogunwolu E. 1990. Damage to cowpea by the legume pod borer, Maruca testulalis Geyer, as influenced by infestation density in Nigeria. Journal Tropical Pest Management 36:138-140. doi: https://doi.org/10.1080/09670879009371457.

Pande S. 2013. Studies on transmission efficiency of Bemisia tabaci in Vigna unguiculata (L.) for Cowpea golden mosaic virus. Elixier Applied Botany 65:19827-19829.

Panizzi AR. 2013. History and contemporary perspectives of the integrated pest management of soybean in Brazil. Neotropical Entomology 42:119-127. doi: https://doi.org/10.1007/s13744013-0111-y.

Pomari-Fernades A, Bueno AdeF, Bueno RCOdeF, Menezes Ajr, Fonseca ACPF. 2013. Releasing number of Telenomus remus (Nixon) (Hymenoptera: Platygastridae) against Spodoptera frugiperda Smith (Lepidoptera: Noctuidae) in corn, cotton and soybean. Cliencia Rural 43:377-382. doi: https://doi.org/10.1590/S010384782013005000013.

Pratissoli D, Dalvi LP, Polandczyk R. Andrade G, Holtz AM, Nicoline HO. 2010. Biological characteristics of Trichogramma exiguum in the eggs of Anagasta kuehniella and Sitotroga cerealella. Idesia 28:39-42. doi: https://doi. org/10.4067/S0718-34292010000100006. 
Prayogo Y. 2012. Toksisitas cendawan entomopatogen Beauveria bassiana terhadap kepik hijau Nezara viridula (L.). Di dalam: Rahmiana AA et al. (Eds.), Prosiding Seminar Hasil Penelitian Tanaman Aneka Kacang dan Umbi (Malang, 5 Juli 2012). hlm. 211-222. Malang: Balitkabi.

Prayogo Y. 2013. Patogenisitas cendawan entomopatogen Beauveria basssiana (Deuteromycotina: Hyphomycetes) pada berbagai stadia kepik hijau (Nezara viridula L.). Jurnal HPT Tropika 13:75-86.

Prayogo Y. 2017. Perbandingan metode aplikasi jamur entomopatogen Beauveria bassiana untuk pengendalian Cylas formicarius (Coleoptera: Curculionidae). Jurnal HPT Tropika 17:84-53. doi: https://doi.org/10.23960/j.hptt.11784-95.

Prayogo Y, Bayu MSYI. 2018. Status and population of arthropod on mungbean. Earth and Environmental Science 197:1-11. doi: https:// doi.org/10.1088/1755-1315/197/1/012032.

Prayogo Y, Tantawizal. 2015. Efikasi biopestisida Beauveria bassiana pada kepik coklat. Di dalam: Rahmianna AA et al. (Eds.), Peran Invovasi Teknologi Aneka Kacang dan Umbi Mendukung Program Kedaulatan Pangan (Malang, $19 \mathrm{Mei}$ 2015). hlm. 284-295. Malang: Balitkabi.

Razaq M, Suhail A, Aslam M, Arif MJ, Saleem MA, Khan HA. 2013. Patterns of insecticides used on cotton before introduction of genetically modified cotton in Southern Punjab, Pakistan. Pakistan Journal of Zoology 45:574-577.

Riaz M, Naqvi SAH. 2014. Predation potential of foliage spiders and estimates of utilization curve, niche breath and overlap in cotton field from Punjab, Pakistan. Journal of Biodiversity and Environmental Sciences 5:264-375.

Ruiu L. 2018. Microbial biopesticides in Agroecosystems. Agronomy 8:1-12. doi: https://doi. org/10.3390/agronomy8110235.

Saeed MBEEEM, Laing MD, Miler RM, Bancole B. 2017. Ovicidal, larvicidal and insecticidal activity of strains of Beauveria bassiana (Balsamo) Vuillemin against the cigarette beetle Lasioderma serricorne Fabricius (Coleoptera: Anobiidae) on rice grain. Journal of Stored Products Research 74:78-86. doi: https://doi. org/10.1016/j.jspr.2017.10.001.

Sharma M, Tarafdar A, Ghosh R, Gopalakrishanan S. 2017. Biological control as a tool for ecofriendly management of plant pathogens. Di dalam: Adhya TK, Mishra BB, Annapurna K, Verma, Kumar U (Eds.), Advances in Soil Microbiology: Recent Trends and Future Prospects, Microorganisms for Sustainability. hlm. 153-186. Singapura: Springer. doi: https:// doi.org/10.1007/978-981-10-7380-9_8.

Singh PS, Mishra H, Singh SK. 2015. Evaluation of certain newer insecticides against the insect pests of mungbean, Vigna radiata (1.) Wilczek . Journal of Experimental Zoology India 19:367-372.

Subhasree S. 2013. Eco-friendly Management Strategies Against Pod Borer Complex of Cowpea Vigna unguiculata var sesquipedalis $L$. Verdcourt. Thesis. Kerala: Kerala Agricultural University.

Udiarto BK, Hidayat P, Rauf A, Pudjianto, Hidayat SH. 2012. Kajian potensi predator Coccinellidae untuk pengendalian Bemisia tabaci (Gennadius) pada cabai merah. Jurnal Hortikultura 22:76-84. doi: https://doi.org/10.21082/jhort.v22n1.2012. p76-84.

Tengkano W, Baliadi Y, Purwantoro. 2011. Pengendalian pengisap polong kedelai Riptortus linearis (L.) dan Nezara viridula (L.) dengan insektisida kimia di lahan kering masam Provinsi Lampung. Di dalam: Widjono A, Hermanto, Nugrahaeni N, Rahmiana NN, Suharsono, Rozi F, Ginting E, Taufiq A, Harsono A, Prayogo Y, Yusnawan Y. (Eds.), Inovasi Teknologi Kacang-kacngan dan Umbi-umbian Mendukung Kemandirian Pangan \& Kecukupan Energi (Malang, 15 November 2011). hlm. 363-370. Malang: Balitkabi

Tumuhaise V, Ekesi S, Mohamed SA, Ndegwa PN. 2015. Pathogenicity and performance of two candidate isolates of Metarhizium anisopliae and Beauveria bassiana (Hypocreales: Clavicipitaceae) in four liquid culture media for the management of the legume pod borer Maruca vitrata (Lepidoptera: Crambidae). International Journal of Tropical Insect Science 35:34-47. doi: https://doi.org/10.1017/S1742758414000605.

Wang Z, Yan H, Yang Y, Wu Y. 2010. Biotype and insecticide resistance status of the whitefly Bemisia tabaci from China. Pest Management Science 66:136-1366. doi: https://doi.org/10.1002/ ps.2023.

Wu SY, Gao YL, Xu XN, Wang DJ, Li J, Wang HH, Lei ZR. 2015. Feeding on Beauveria bassianatreated Frankliniella occidentalis causes negative effects on the predatory mite Neoseiulus barkeri. Scientific Reports 5:12033. doi: https:// doi.org/10.1038/srep12033.

Zahid MA, Islam MM, Begum MR. 2008. Determination of economic injury level of Maruca vitrata in mungbean. Journal Agriculture Rural Development 6:91-97. doi: https://doi. org/10.3329/jard.v6i1.1662. 